\title{
Instructional Video using Wondershare Filmora 9 in the Interpretive Reading Course for English Language Education Students
}

\author{
Ni Made Yuniari ${ }^{*}$, I Gusti Ayu Indah Triana Juliari² (D) \\ ${ }^{1,2}$ Pendidikan Bahasa Inggris, Universitas Dwijendra, Denpasar, Indonesia \\ *Corresponding author: yuniari6868@gmail.com
}

\begin{abstract}
Abstrak
Pandemi Covid-19 memberi dampak yang signifikan terhadap pendidikan. Pelaksanaan pembelajaran daring mengakibatkan kurangnya ketersediaan media pembelajaran yang tepat untuk mendukung pelaksanaan pembelajaran daring. Penelitian ini bertujuan untuk mengembangkan video pembelajaran menggunakan Wondershare Filmora 9 dalam mata kuliah Interpretive Reading untuk mahasiswa semester tiga Pendidikan Bahasa Inggris. Pengembangan video pembelajaran ini menggunakan model pengembangan ADDIE yang terdiri dari tahap analisis, desain, pengembangan, implementasi, dan tahap evaluasi. Hasil validitas pengembangan multimedia interaktif akan dipaparkan dua hal pokok yang meliputi: ahli mata pelajaran, dan ahli media pembelajaran, Subjek penelitian ini meliputi para ahli yaitu 2 ahli mata pelajaran, dan 2 ahli media pembelajaran, Metode yang digunakan dalam mengumpulkan data yaitu metode observasi, metode wawancara, dan metode kuesioner. Teknik analisis data pada penelitian ini yaitu deskriptif kualitatif dan deskriptif kuantitatif. Instrumen pengumpulan data dalam penelitian ini yaitu menggunakan kuesioner. Hasil validasi yang dilakukan oleh ahli materi I dan II adalah 93,84\%, sedangkan hasil validasi yang dilakukan oleh ahli media I dan II adalah 87,05\%. Dapat disimpulkan bahwa video pembelajaran yang telah dikembangkan dengan bantuan Wondershare Filmora 9 sangat layak untuk digunakan dalam mata kuliah interpretative reading. Berdasarkan hasil dan simpulan tersebut, video pembelajaran dapat digunakan sebagai alternatif dalam mengatasi permasalahan tentang kurangnya ketersediaan media dalam pembelajaran daring.
\end{abstract}

Kata kunci: Video Pembelajaran, Wondershare Filmora 9, Interpretive Reading

\section{Abstract}

The Covid-19 pandemic has had a significant impact on education. The implementation of online learning results in the lack of availability of appropriate learning media to support the implementation of online learning. This study aims to develop learning videos using Wondershare Filmora 9 in the Interpretive Reading course for third semester students of English Education. The development of this learning video uses the ADDIE development model which consists of the analysis, design, development, implementation, and evaluation stages. The results of the validity of interactive multimedia development will be presented with two main points which include: subject matter experts, and learning media experts. The subjects of this research include experts, namely 2 subject experts, and 2 learning media experts. The method used in collecting data is the observation method, interview method, and questionnaire method. The data analysis technique in this research is descriptive qualitative and descriptive quantitative. The data collection instrument in this study was using a questionnaire. The results of the validation carried out by material experts I and II were $93.84 \%$, while the results of the validation carried out by media experts I and II were $87.05 \%$. It can be concluded that the learning video that has been developed with the help of Wondershare Filmora 9 is very suitable for use in interpretive reading courses. Based on these results and conclusions, learning videos can be used as an alternative in overcoming the problem of the lack of media availability in online learning.

Keywords: Learning Video, Wondershare Filmora 9, Interpretive Reading

$\begin{array}{ll}\text { History: } & \text { Publisher: Undiksha Press } \\ \text { Received : January 19, } 2021 & \text { Licensed: This work is licensed under } \\ \text { Revised : March 03, } 2021 & \text { a Creative Commons Attribution 3.0 License } \\ \text { Accepted : April 04, 2021 } & \text { Published : April 25, 2021 }\end{array}$

\section{INTRODUCTION}

Learning media as a tool used for means of channeling information about the subject matter, can help students experience the learning process in themselves to achieve learning goals (Ayuningsih, 2017; Fonda \& Sumargiyani, 2018). Using learning media can help generate students' motivation and interest to improve students' understanding (Falloon, 2020; Maharani, 2015). The use of learning media in the learning process is very important to be 
systematically designed so that the learning media is effective for use. Learning media can optimize the learning process of students in learning that is expected to optimize the learning outcomes achieved (Komikesari et al., 2020; Pratama \& Retnawati, 2018). Some reasons why learning media can optimize the learning process of students, namely teaching will attract more attention of students. So that it can add motivation to learning, teaching materials will be clearer meaning so that it can be better understood by students and allow students to be able to achieve learning purposes better (Bajrami \& Ismaili, 2016; Dewi et al., 2018). Learning methods will be more varied not only verbal communication through speech by teachers so that students do not get bored and teachers do not run out of energy especially if the teacher teaches for every hour of learning (Andriyani \& Suniasih, 2021; Prabaningrum \& Putra, 2019). Students do more learning activities because not only listen to the teacher's description but also other activities such as observing, doing, demonstrating, and others.

Currently the world is still experiencing the impact of Covid-19. Education is one of the areas that affected by Covid-19 (Garbe et al., 2020; Obiakor \& Adeniran, 2020). Online learning has been going on for 2 years and is still ongoing. But now face-to-face learning has begun, although it is still limited (Basar, 2021). So that blended learning is the only option that can be applied at this time (Auma \& Achieng, 2020). These problems still require educators to be creative and innovate in developing learning media that attract students' interest. Today's technology really helps educators to be more creative in creating their own learning videos. At the beginning of the pandemic, educators still did not dare to use their own Instructional videos because they lacked experience and lacked knowledge in designing their own learning videos (Jundu et al., 2020; Qurrotaini et al., 2020). They still used Instructional videos that already exist on YouTube and send the video link to their students. But over time, educators began to try to make their own Instructional videos by using video editing applications.

There are various kinds of video editing applications that have sprung up. These applications are quite easy to use or operate, especially if used by beginners. One video editing application that is quite easy to operate is Wondershare Filmora 9. Besides being easy to operate, this application also has other advantages such as being quite light, the editing process can be faster, many effects and designs available. Based on the explanation above, the researcher is interested in developing learning videos using Wondershare Filmora 9. This is because learning through instructional videos using Wondershare Filmora is considered quite effective and very functional, especially during the Covid-19 pandemic, which still exists today. There are many benefits that can be obtained by students such as students being able to study independently, student study time is more flexible because learning videos can be watched anytime and anywhere, and students can watch learning videos repeatedly until they understand. Therefore, the author decided to conduct a research entitled The Development of Instructional Video using Wondershare Filmora 9 in Interpretive Reading Courses for Third Semester Students of English Language Education Study Program Dwijendra University. This study aims to develop an instructional video using Wondershare Filmora 9 in the Interpretive Reading course for third semester students of English Language Education Study Program Dwijendra University and to determine the feasibility of a learning video using Wondershare Filmora in 9 the Interpretive Reading course.

\section{METHODS}

This type of research is development. This development research model uses the ADDIE model, consists of five steps, namely: analyze, design, development, implementation, and evaluation (Alnajdi, 2018; Cahyadi, 2019). Analysis is conducted to obtain information related to everything needed in the research. The analysis procedure in this development 
includes several stages, namely analyzing the needs, analyzing materials, determining Basic Competencies and Indicators, the stage of planning is carried out to facilitate the process of making products so that the products produced have a definite design. The design procedure includes several things such as data collection, video scripts and storyboards, this stage of development is carried out the production of learning videos with a predetermined design. Learning content creation, learning design is done in Microsoft PowerPoint and dubbing, back sound and editing are done in application. The video is saved in MP4 format by adjusting the video resolution quality to make the image look clearer but has a size that is not too large so it is easy to share and save, the implementation stage at this stage after the product is validated by experts and produce products in a viable category then the product is ready to be implemented on the test subject. However, it cannot be implemented because covid-19 should not be crowded, this evaluation stage is done after the data at the implementation stage is collected. Evaluation is done in the form of summative evaluation. Summative evaluations are conducted to measure or assess learning products that include expert validation, individual trials, small group trials. The test subject of this development research con

The instrument used to collect data was a questionnaire. Questionnaires were used to determine the feasibility level of instructional video. From the questionnaire validation above each item on it classified in 5 scale and each scale have a certain score, they are very good that will give score 5, good will give score 4, fair will give score 3, poor will give score 2, and very poor will give score 1 . Furthermore, the indicator category for each item called high $(\mathrm{H})$ if the score greater-than or equal to $3(\geq 3)$ and called low $(\mathrm{L})$ if the score less-than $3(<3)$. After that, the data transform into qualitative data with high percentage is $100 \%$ and low percentage is $0 \%$. The next is the data will describe qualitatively. Range is maximal score minus minimal score, and the result is $100 \%$, also large of interval (100\% divided 5 scale) equal $20 \%$. So, based on the count up, range percentage and the qualitative category in Table 1 .

Table 1. Range Percentage and Qualitative Criteria

\begin{tabular}{cc}
\hline Percentage & Category \\
\hline $81 \%<$ score $<100 \%$ & Very good \\
$61 \%<$ score $<80 \%$ & Good \\
$41 \%<$ score $<60 \%$ & Fair \\
$21 \%<\operatorname{score}<40 \%$ & Poor \\
$0 \%<$ score $<20 \%$ & Very Poor \\
\hline
\end{tabular}

\section{RESULTS AND DISCUSSION}

\section{Results}

The final product that has been developed in this research is an instructional video in interpretive reading courses that can be used in the learning process. The learning video development process is carried out using the ADDIE development model. The stages carried out in this research and development consist of 5 stages, namely (1) Analysis, (2) Design, (3) Development, (4) Implementation, and (5) Evaluation. This development process begun with an analysis. At this stage of analysis, researchers obtain information through interviews with lecturers who teach interpretive reading courses. The interview contained about how the learning process took place, what media were used when teaching, and what materials were in the lesson plan. In the second stage, namely design, at this stage the researcher made the initial design of the instructional video by preparing the material, background, back sound, flowchart and storyboard design, as well as the Wondershare Filmora application. The 
learning material raised by the researcher was genre text where the materials were obtained from the lesson plan and the rest of the material needs were obtained from various sources on the internet. In the third stage, namely development, the making of instructional videos was carried out according to the designs that have been made at the design stage. In this stage, the Wondershare Filmora application was used. The process of this stage begun with an opening that started with a brief review of the material that had been taught previously, then continued with a discussion of the material, and finally assigned the task via google form. The material would be displayed in the form of text, images, audio and exercises on instructional video that were processed with the Wondershare Filmora application. Researchers recorded audio using the voice recorder in the application.

In the fourth stage, namely implementation, validation or assessment was carried out by material experts and media experts. The implementation of this stage was carried out by researchers by submitting instructional videos and questionnaires to media experts and material experts. Then the researchers waited for responses from experts in the form of validation results and suggestions. The data from the validation was then used as a reference in improving the instructional video. In the final stage, namely the evaluation, the improvement process was carried out based on suggestions from material experts and media experts as well as the calculation of the validation data given to determine the feasibility of the instructional video. The feasibility of this Wondershare Filmora learning video was carried out through assessment or validation by material experts and media experts. Aspects assessed by material experts include learning aspects, material aspects, and benefits aspects. Meanwhile, the aspects assessed by media experts include visual aspects, media aspects, and benefits aspects. Based on the results of the validation carried out by the material expert I, the percentage was $90,8 \%$, while the validation results from the material expert 2 were $96,9 \%$. Then from the results of the validation of the two experts, an average of $93,84 \%$ could be calculated. The validation result of material experts is presented in Table 2.

Table 2. Validation Result of Material Expert

\begin{tabular}{|c|c|c|c|c|c|c|c|}
\hline \multicolumn{4}{|c|}{ Expert I } & \multicolumn{4}{|c|}{ Expert II } \\
\hline No. & Items & Scale & Category & No. & Items & Scale & Category \\
\hline 1 & 1 & 5 & $\mathrm{H}$ & 1 & 1 & 5 & $\mathrm{H}$ \\
\hline 2 & 2 & 5 & $\mathrm{H}$ & 2 & 2 & 5 & $\mathrm{H}$ \\
\hline 3 & 3 & 4 & $\mathrm{H}$ & 3 & 3 & 5 & $\mathrm{H}$ \\
\hline 4 & 4 & 4 & $\mathrm{H}$ & 4 & 4 & 5 & $\mathrm{H}$ \\
\hline 5 & 5 & 4 & $\mathrm{H}$ & 5 & 5 & 4 & $\mathrm{H}$ \\
\hline 6 & 6 & 5 & $\mathrm{H}$ & 6 & 6 & 5 & $\mathrm{H}$ \\
\hline 7 & 7 & 5 & $\mathrm{H}$ & 7 & 7 & 5 & $\mathrm{H}$ \\
\hline 8 & 8 & 5 & $\mathrm{H}$ & 8 & 8 & 5 & $\mathrm{H}$ \\
\hline 9 & 9 & 4 & $\mathrm{H}$ & 9 & 9 & 5 & $\mathrm{H}$ \\
\hline 10 & 10 & 4 & $\mathrm{H}$ & 10 & 10 & 4 & $\mathrm{H}$ \\
\hline 11 & 11 & 5 & $\mathrm{H}$ & 11 & 11 & 5 & $\mathrm{H}$ \\
\hline 12 & 12 & 5 & $\mathrm{H}$ & 12 & 12 & 5 & $\mathrm{H}$ \\
\hline 13 & 13 & 4 & $\mathrm{H}$ & 13 & 13 & 5 & $\mathrm{H}$ \\
\hline \multicolumn{2}{|r|}{ n } & \multicolumn{2}{|c|}{59} & \multicolumn{2}{|c|}{$\mathbf{n}$} & \multicolumn{2}{|c|}{63} \\
\hline \multicolumn{2}{|c|}{$\mathbf{N}$} & \multicolumn{2}{|c|}{65} & \multicolumn{2}{|c|}{$\mathbf{N}$} & \multicolumn{2}{|c|}{65} \\
\hline \multicolumn{2}{|c|}{$\%$} & \multicolumn{2}{|c|}{$90.8 \%$} & \multicolumn{2}{|c|}{$\%$} & \multicolumn{2}{|c|}{$96.9 \%$} \\
\hline
\end{tabular}

According to average of percentage result of the material experts in Table 2, the category of qualitative is very good based on education criteria. So, the writer can conclude 
that this instructional video was valid according to educational criteria and ready to implement in the class. Based on the results of the validation carried out by the media expert I, the percentage was $84,7 \%$, while the validation results from the media expert II were $89,4 \%$. Then from the results of the validation of the two media experts, an average of 87, 05 $\%$ could be calculated. The validation result of media experts is presented in Table 3.

Table 3. Validation Result of Media Expert

\begin{tabular}{|c|c|c|c|c|c|c|c|}
\hline \multicolumn{4}{|c|}{ Expert I } & \multicolumn{4}{|c|}{ Expert II } \\
\hline No. & Items & Scale & Category & No. & Items & Scale & Category \\
\hline 1 & 1 & 4 & $\mathrm{H}$ & 1 & 1 & 3 & $\mathrm{H}$ \\
\hline 2 & 2 & 4 & $\mathrm{H}$ & 2 & 2 & 2 & $\mathrm{H}$ \\
\hline 3 & 3 & 5 & $\mathrm{H}$ & 3 & 3 & 5 & $\mathrm{H}$ \\
\hline 4 & 4 & 5 & $\mathrm{H}$ & 4 & 4 & 5 & $\mathrm{H}$ \\
\hline 5 & 5 & 4 & $\mathrm{H}$ & 5 & 5 & 4 & $\mathrm{H}$ \\
\hline 6 & 6 & 4 & $\mathrm{H}$ & 6 & 6 & 3 & $\mathrm{H}$ \\
\hline 7 & 7 & 4 & $\mathrm{H}$ & 7 & 7 & 5 & $\mathrm{H}$ \\
\hline 8 & 8 & 4 & $\mathrm{H}$ & 8 & 8 & 5 & $\mathrm{H}$ \\
\hline 9 & 9 & 4 & $\mathrm{H}$ & 9 & 9 & 5 & $\mathrm{H}$ \\
\hline 10 & 10 & 5 & $\mathrm{H}$ & 10 & 10 & 5 & $\mathrm{H}$ \\
\hline 11 & 11 & 4 & $\mathrm{H}$ & 11 & 11 & 5 & $\mathrm{H}$ \\
\hline 12 & 12 & 3 & $\mathrm{H}$ & 12 & 12 & 5 & $\mathrm{H}$ \\
\hline 13 & 13 & 4 & $\mathrm{H}$ & 13 & 13 & 5 & $\mathrm{H}$ \\
\hline 14 & 14 & 4 & $\mathrm{H}$ & 14 & 14 & 4 & $\mathrm{H}$ \\
\hline 15 & 15 & 5 & $\mathrm{H}$ & 15 & 15 & 5 & $\mathrm{H}$ \\
\hline 16 & 16 & 5 & $\mathrm{H}$ & 16 & 16 & 5 & $\mathrm{H}$ \\
\hline 17 & 17 & 4 & $\mathrm{H}$ & 17 & 17 & 5 & $\mathrm{H}$ \\
\hline n & & 72 & & & & 76 & \\
\hline $\mathbf{N}$ & & 85 & & $\mathrm{~J}$ & & 85 & \\
\hline$\%$ & & $84.7 \%$ & & $\%$ & & $89.4 \%$ & \\
\hline
\end{tabular}

\section{Discussion}

Based on the results of reviews from learning content experts, the results of the calculation of the value are $93.84 \%$ so that they are in very good qualifications. Very good qualifications can be achieved due to several things, namely (1) the clarity of the mapping of basic competencies, indicators, and learning objectives contained in interactive multimedia, (2) systematic suitability, material content, and depth of material presented in interactive multimedia, (3) on the language aspect of the clarity of information can be conveyed well, the use of language and the legibility of the text is clear, and (4) the clarity of the formulation of the evaluation questions, and the level of difficulty of the questions are appropriate. This is in line with research which states that the clarity of indicators and learning objectives will improve the quality of learning (Hidayah \& Priscylio, 2019; Hidayat et al., 2020). A coherent presentation of the material will be interesting and easier for students to understand (Fitri \& Karmila, 2018; Nurafni et al., 2020). This can be proven from the results of the assessment of learning content experts on instrument items related to the suitability of learning indicators with material in interactive multimedia obtaining a percentage $(100 \%)$ with very good criteria, and on instrument items related to presenting material in a coherent manner obtaining a percentage $(100 \%)$ with criteria very good.

This opinion is supported by the results of research which shows that the delivery of learning materials through the use of multimedia in which there are elements such as text, 
images, sound, video and animation in accordance with the material is effective for clarifying the material presented and can increase students' interest and motivation in the process. Learning (Jundu et al., 2020; Pratiwi et al., 2019). his opinion is supported by the results of research which shows that the delivery of learning materials through the use of multimedia in which there are elements such as text, images, sound, video and animation in accordance with the material is effective for clarifying the material presented and can increase students' interest and motivation in the learning process (Rante et al., 2013; Yogiyatno \& Sofyan, 2013). This can be proven by the results of the assessment of the learning media experts regarding the items of the suitability of the text type and the readability of the text obtaining a percentage $(100 \%)$ with very good criteria, on the items of the image, video, audio, and animation resolution quality instruments obtaining a percentage $(100 \%)$ with very good criteria, as well as on the consistency of the material presentation instrument items get a percentage $(100 \%)$ with very good criteria.

Besides that, the media experts also gave suggestion related to layout criteria for the instructional video. The suggestions from them were used to revise this product, the suggestions were the background color of the instructional should be revised become lighter color, the animation/picture of the instructional video should be more colorful, and the font of the instructional video should be more interesting. Meanwhile, the material experts suggested that the duration of the instructional video should be no more than 30 minutes, so that students who watched that video would not lose focus because the video duration was too long. This tends to make students bored to hear explanations that are too long.

Furthermore, this research could be compared with the finding of the previous research. The first research entitled Developing Instructional Video for Online Literal Reading Course (Yuniari \& Juliari, 2020). The finding of this research is the highest average percentage from all aspects was the practicability aspect (93\%). This was because the Instructional Video was easy to operate. While, the lowest average percentage from all aspects was the content aspect $(86,25 \%)$. It was because the relation between material and daily life was not related well. Another research entitled developing Instructional Video for Online Literal Reading Course (Juliari et al., 2021). The finding of this research are the highest average percentage from four aspects was pedagogical aspect. It was about $94 \%$ data were categorized valid. Meanwhile, the content aspect was the aspect that got the lowest average percentage of $87,22 \%$. It could be concluded that (1) the use of instructional video could improve students' attention and motivation in learning English. (2) The students could learn and practice English independently at home without time limitation. By doing this, the students are able to use English on their daily activities. Thus, they could achieve the communicative competence. (3) The use of Instructional Video for online English subject was appropriate used as the teaching media for third grade students at SD Dwijendra Denpasar.

\section{CONCLUSION}

The instructional videos that have been developed using the assistance of Wondershare Filmora were very appropriate to be used in interpretive reading courses. There were several revisions and suggestions from experts, such as the background used in the video should be brighter so that the color of the writing can be read clearly, the animation or image used must be sharper or not cracked to make it more comfortable to see, the letters used are replaced with the attractive ones, and the duration of the instructional video should be no more than 30 minutes, so that students who watched that video would not lose focus because the video duration was too long. 


\section{REFERENCES}

Alnajdi, S. M. (2018). The Effectiveness of Designing and Using a Practical Interactive Lesson based on ADDIE Model to Enhance Students' Learning Performances in University of Tabuk. Journal of Education and Learning, 7(6), 212. https://doi.org/10.5539/jel.v7n6p212.

Andriyani, N. L., \& Suniasih, N. W. (2021). Development of Learning Videos Based On Problem-Solving Characteristics of Animals And Their Habitats Contain in Science Subjects on 6th-Grade. Journal of Education Technology, 5(1), 37-47. https://doi.org/10.23887/jet.v5i1.32314.

Auma, O. M., \& Achieng, J. (2020). Perception of Teachers on Effectiveness of Online Learning in the wake of COVID-19 Pandemic. IOSR Journal Of Humanities And Social Science (IOSR-JHSS, 25(6), 19-28. https://doi.org/10.9790/0837-2506111928.

Ayuningsih, K. (2017). Pengaruh Video Animasi Terhadap Hasil Belajar Kognitif Pada Mata Pelajaran IPS Materi Menghargai Jasa Pahlawan di Kelas V SDN Sidokumpul Sidoarjo. JICTE (Journal of Information and Computer Technology Education), 1(1), 43. https://doi.org/10.21070/jicte.v1i1.1129.

Bajrami, L., \& Ismaili, M. (2016). The Role of Video Materials in EFL Classrooms. Procedia - Social and Behavioral Sciences, 232(April), 502-506. https://doi.org/10.1016/j.sbspro.2016.10.068.

Basar, A. M. (2021). Problematika Pembelajaran Jarak Jauh Pada Masa Pandemi Covid-19. Edunesia: Jurnal Ilmiah Pendidikan, 2(1), 208-218. https://doi.org/10.51276/edu.v2i1.112.

Cahyadi, R. A. H. (2019). Pengembangan Bahan Ajar Berbasis Addie Model. Halaqa: Islamic Education Journal, 3(1), 35. https://doi.org/10.21070/halaqa.v3i1.2124.

Dewi, N. R., Kannapiran, S., \& Wibowo, S. W. A. (2018). Development of digital storytelling-based science teaching materials to improve students' metacognitive ability. Jurnal Pendidikan IPA Indonesia, 7(1), 16-24. https://doi.org/10.15294/jpii.v7i1.12718.

Falloon, G. (2020). From digital literacy to digital competence: the teacher digital competency (TDC) framework. Educational Technology Research and Development, 68(5), 2449-2472. https://doi.org/10.1007/s11423-020-09767-4.

Fitri, N. A., \& Karmila. (2018). Pengembangan Media Pop-Up Book Kubus dan Balok untuk Siswa Kelas V Sekolah Dasar. PEDADIDAKTIKA: Jurnal Ilmiah Pendidikan Guru Sekolah Dasar, 5(4), 226-239.

Fonda, A., \& Sumargiyani, S. (2018). The Developing Math Electronic Module With Scientific Approach Using Kvisoft Flipbook Maker Pro For Xi Grade Of Senior High School Students. Infinity Journal, 7(2), 109-122. https://doi.org/10.22460/infinity.v7i2.p109-122.

Garbe, A., Ogurlu, U., Logan, N., \& Cook, P. (2020). Parents' experiences with remote education during COVID-19 school closures. American Journal of Qualitative Research, 4(3), 45-65. https://doi.org/10.29333/ajqr/8471.

Hidayah, D. N., \& Priscylio, G. (2019). Pengembangan Bahan Ajar Mandiri Pokok Bahasan Suhu Dan Kalor Menggunakan Software Camtasia. Journal of Teaching and Learning Physics, 4(1), 50-64. https://doi.org/10.15575/jotalp.v4i1.4093.

Hidayat, H., Mulyani, H., Nurhasanah, S. D., Khairunnisa, W., \& Sholihah, Z. (2020). Peranan Teknologi Dan Media Pembelajaran Bagi Siswa Sekolah Dasar Di Dalam Pembelajaran Pendidikan Kewarganegaraan. Jurnal Pendidikan Kewarganegaraan Undiksha, 8(2), 35-46. https://doi.org/10.23887/jpku.v8i2.24759.

Juliari, I. G. A. I. T., Yuniari, N. M., \& Sudarmawan, I. P. . (2021). The Development of Instructional Video for Online English Subject at SD Dwijendra Denpasar. LEJU 
(Language and Education Journal Undiksha), 4(2), 106-113. https://doi.org/10.23887/leju.v4i2.37613.

Jundu, R., Nendi, F., Kurnila, V. S., Mulu, H., Ningsi, G. P., \& Ali, F. A. (2020). Pengembangan Video Pembelajaran IPA Berbasis Kontekstual Di Manggarai Untuk Belajar Siswa Pada Masa Pandemic Covid-19. LENSA (Lentera Sains): Jurnal Pendidikan IPA, 10(2), 63-73. https://doi.org/10.24929/lensa.v10i2.112.

Komikesari, H., Mutoharoh, M., Dewi, P. S., Utami, G. N., Anggraini, W., \& Himmah, E. F. (2020). Development of e-module using flip pdf professional on temperature and heat material. Journal of Physics: Conference Series, 1572(1). https://doi.org/10.1088/1742-6596/1572/1/012017.

Maharani, Y. S. (2015). Efektivitas Multimedia Pembelajaran Interaktif Berbasis Kurikulum 2013. Indonesian Journal of Curriculum and Educational Technology Studies, 3(1), 31-40. https://doi.org/10.15294/ijcets.v3i1.8683.

Nurafni, A., Pujiastuti, H., \& Mutaqin, A. (2020). Pengembangan Bahan Ajar Trigonometri Berbasis Kearifan Lokal. Journal of Medives: Journal of Mathematics Education IKIP Veteran Semarang, 4(1), 71. https://doi.org/10.31331/medivesveteran.v4i1.978.

Obiakor, T., \& Adeniran, A. (2020). COVID-19: Risk-control measures threaten to deepen Nigeria's education crisis. Centre for the Study of Economies of Africa (CSEA). Centre for the Study of Economies of Africa (CSEA). http://cseaafrica.org/covid-19risk-control-measures-threatens-to-deepen-nigerias- education-crisis/.

Prabaningrum, \& Putra. (2019). Pengaruh Model Pembelajaran Kooperatif Team Assisted Individualization Berbantuan Media Semi Konkret Terhadap Kompetensi Pengetahuan Matematika. Jurnal Ilmiah Sekolah Dasar, 3(4), 414. https://doi.org/10.23887/jisd.v3i4.21775.

Pratama, G. S., \& Retnawati, H. (2018). Urgency of Higher Order Thinking Skills (HOTS) Content Analysis in Mathematics Textbook. Journal of Physics: Conference Series, 1097(1). https://doi.org/10.1088/1742-6596/1097/1/012147.

Pratiwi, E. D., Latifah, S., \& Mustari, M. (2019). Pengembangan Media Pembelajaran Fisika Menggunakan Sparkol Videoscribe. Indonesian Journal of Science and Mathematics Education, 2(3), 303-309. https://doi.org/10.24042/ijsme.v2i3.4355.

Qurrotaini, L., Sari, T. W., \& Sundi, V. H. (2020). Efektivitas Penggunaan Media Video Berbasis Powtoon dalam Pembelajaran Daring. Prosiding Seminar Nasional Penelitian LPPM UMJ, E-ISSN: 27, 7.

Rante, P., Sudarto, \& Ihsan, N. (2013). Pengembangan multimedia pembelajaran fisika berbasis audio-video eksperimen listrik dinamis di smp. Jurnal Pendidikan IPA Indonesia, 2(2), 203-208. https://doi.org/10.15294/jpii.v2i2.2724.

Yogiyatno, W., \& Sofyan, H. (2013). Pengembangan multimedia interaktif kompetensi dasar mengoperasikan software basis data untuk SMK Negeri 1 Seyegan. Jurnal Pendidikan Vokasi, 3(3), 391-404. https://doi.org/10.21831/jpv.v3i3.1851.

Yuniari, N. ., \& Juliari, I. G. A. I. T. (2020). Developing Instructional Video for Online Literal Reading Course. LEJU (Language and Education Journal Undiksha), 3(2), 39-46. https://doi.org/10.23887/leju.v3i2.25104. 